\title{
Early Experiences with Studer's Orthotopic Neobladder
}

\author{
Bharat Bahadur Bhandari ${ }^{1}$,Bikash Bikram Thapa ${ }^{1}$, Narayan Thapa ${ }^{1}$, Bhairab Kumar Hamal'. \\ ${ }^{1}$ Department of surgery, Shree Birendra Hospital, Kathmandu, Nepal.
}

\begin{abstract}
Introduction: Radical cystectomy and urinary diversion is the standard treatment option for muscle invasive urothelial carcinoma of urinary bladder. We analyzed the complications and functional outcome of 21 consecutive patients who underwent radical cystectomy and studer ileal neobladder substitution.

Methods: This was a retrospective study from the review of chart and follow up details of 21 patients who underwent radical cystectomy and Studer ileal neobladder substitution from January 2009 to February 2014. Data obtained were the disease characteristics, both the early and late complications and urinary continence.

Results: Total 21 patients were evaluated. 17 patients were available for follow up of one year or more. One patient died secondary to surgery related complications and 2 died due to exacerbation of comorbidities. And one patient lost follow up after one year. The rates of early and late morbidity were $33.3 \%$ (7) and 19\% (4). Prolonged ileus developed in three patients and urinary tract infection was the most common among early and late complications $(2,8 \%)$. Two patients developed anastomotic stricture. Complete day time and night time continence was achieved in $82 \%$ (14) and 33.3\% (7) respectively. The mean maximum neobladder capacity at end of one year was $345 \mathrm{ml}$.
\end{abstract}

Conclusions: Outcome of studer's ileal orhtotopic neobladder in our series is comparable with others. The result of our study is promising and encouraging to pursue it as a primary treatment option for muscle invasive and recurrent urothelial carcinoma of urinary bladder.

Keywords: invasive urothelial carcinoma; radical cystectomy; sutder's orthotopoic neobladder; nocturnal incontinence.

\section{INTRODUCTION}

The worldwide incidence of bladder cancer is 386,000 per year ${ }^{1}$. It represents $4.7 \%$ of all cancers in men and $1.5 \%$ in female. Histologically $90 \%$ of bladder cancers are of urothelial origin and urothelial carcinoma is the second most common genitourinary tumors ${ }^{2}$. Urothelial carcinoma of urinary bladder was the $12^{\text {th }}$ most common cancer visiting BP koirala Memorial Cancer Hospital and commonest among urological malignancy ${ }^{3}$. Radical cystectomy for urothelial carcinoma of urinary bladder serves as the gold standard for local control and survival of muscle invasive tumors and for recurrent and refractory tumors following bladder preservation therapies ${ }^{4}$.

The goal of urinary diversion after radical cystectomy is not only simple diversion and protection of the upper tracts but also the natural functional and anatomic restoration of urinary tract. Since 1980 AD orthotopic reconstruction has evolved from "experimental surgery" to "standard of care at larger medical centers" to the "preferred method of urinary diversion" in both sexes $^{5}$. The use of the ileum for orthotopic bladder substitution has gained general acceptance within the past decade, and orthotopic continent diversions have

\section{Correspondence:}

Bharat Bahadur Bhandari

Department of Surgery, Shree Birendra Hospital, Kathmandu, Nepal.

E-mail: drbharatbhandari@yahoo 
become the "gold standard" reconstructive procedure after radical cystectomy ${ }^{6}$.

\section{METHODS}

Between January 2009 and February 2014, we performed 21 consecutive radical cystectomy and pelvic lymphadenectomy with urinary diversion by a Studer bladder substitute for the management of muscle invasive urinary bladder cancer and high risk bladder cancer. The criteria for selection was based on disease stage, renal and liver function, patient's choice of urinary diversion and compliance with routine follow up.

The cystectomy was performed following the standard procedure and the extent of lymph node dissection was decided by surgeon depending on the preoperative staging. The reservoir was constructed by isolating a $45 \mathrm{~cm}$ ileal segment about $15 \mathrm{~cm}$ proximal to the ileocecal valve (figure.1). The technique of the ileal neo bladder substitution has been followed after the studer et al. ${ }^{7,8,9}$ The pouch was then sutured to the edge of membranous urethra with a silicon catheter in situ. Cystostoma was placed in all cases. For the first week of the postoperative period, the reservoir was irrigated with $50 \mathrm{cc}$ saline solution every four hours in order to dissolve mucous inside the reservoir. The ureteral stents were left inside for one week and were irrigated as needed. Three weeks postoperatively, pouchogram was done to evaluate for leakage, reflux, and anastomotic site stricture.

All patients were educated on how to reduce post-void residual urine and how to increase voiding volume and intervals. Initially, they were taught to empty the pouch less than 4 hours in a sitting position by relaxing the pelvic floor and increasing intra-abdominal pressure by valsalval maneuver. Our patients were followed regularly every 3 months for 2 years and then at yearly intervals thereafter. Out of 21 patients only 17 were available for follow up for more than one year.

Oncological and functional outcome was evaluated which included clinical, laboratory and metabolic assessments, and imaging procedures. Complete continence was defined as no involuntarily loss of urine and no pad use. Early and late complications were defined as complications that developed post operatively within 30 days and beyond 30 days. ${ }^{9}$ Complications were defined as graded according to a modified Dindo-Clavein classification. ${ }^{10}$ Variables evaluated include preoperative patient demographics, operative parameters post-operative parameters, pathological features, median survival and functional outcome. Values are expressed as means plus or minus standard deviation. Data were analyzed using SPSS 16.0 (SPSS Inc., Chicago, USA.)

\section{RESULTS}

We evaluated 21 male patients aged between 48 to 69 years who had undergone radical cystectoprostatectomy and orthotopoic ileal neobladder substitution. Details of patient's characteristics and operative details are outlined in table. 1. The pathological stage of the disease were Stage 0a (2), Stage 0is (1), Stage I (4), Stage II (10), Stage III (2) and stage IV (2) with no distant metastasis in all cases.

Table 1. Patient demographics $(\mathrm{n}=\mathbf{2 5})$

\begin{tabular}{|l|l|}
\hline Age ( years) & $60 \pm 9.2$ \\
\hline Underlying disease & \\
\hline Diabetes & 2 \\
\hline Hypertension & 2 \\
\hline Respiratory Disease & 1 \\
\hline ASA score & \\
\hline I & $9(42.8 \%)$ \\
\hline II & $12(57.2 \%)$ \\
\hline III & 0 \\
\hline Hospital stay ( days) & $28.6 \pm 11.5$ \\
\hline Follow up duration (months) & $58.2 \pm 30.4$ \\
\hline Total operative time ( min) & $396.1 \pm 65.4$ \\
\hline Estimated blood loss (ml) & $767 \pm 298.9$ \\
\hline Transfusion (n, \%) & $9(42.8 \%)$ \\
\hline $\begin{array}{l}\text { Number of dissected lymph } \\
\text { node }\end{array}$ & $10.7 \pm 8.8$ \\
\hline Pathological Stage (n, \%) & \\
\hline Tis & $1(4.7)$ \\
\hline Ta & $2(9.5)$ \\
\hline T1 & $4(19)$ \\
\hline T2 & $11(47.6)$ \\
\hline T3 & $3(14.2)$ \\
\hline T4 & 0 \\
\hline
\end{tabular}




\begin{tabular}{|l|l|}
\hline $\begin{array}{l}\text { Pathological node positive } \\
(\mathrm{n}, \%)\end{array}$ & 2 (9.5) \\
\hline $\begin{array}{l}\text { Resection margin positive } \\
(\mathrm{n}, \%)\end{array}$ & 0 \\
\hline $\begin{array}{l}\text { Median survival time } \\
\text { (months) }\end{array}$ & 60.3 \\
\hline
\end{tabular}

Complications were assessed in short term (within 30 days) and long term (90 days) which were $33.3 \%$ (7) and $19 \%$ (4) respectively. The perioperative mortality is $1(4.7 \%)$.) The mortality in periopeative period was due to severe sepsis secondary to anastomotic leakage. Three patients died during follow up, one due to surgical complications (acute intestinal obstruction) and other two secondary to chronic cardiaopulmonary diseases.

Table 2. Functional Outcome of $\mathbf{2 0}$ patients evaluated at $\mathbf{1}$ year or more.

\begin{tabular}{|l|l|l|}
\hline Complete Continence & At 6 months $(\mathrm{n}=19)$ & At 1 year $(\mathrm{n}=17)$ \\
\hline Day time & $14(73.3 \%)$ & $14(82 \%)$ \\
\hline Night time & $6(31.5 \%)$ & $7(33.3 \%)$ \\
\hline Mean Maximum Bladder capacity $(\mathrm{ml})$ & 280 & 345 \\
\hline Mean maximum Residual Volume $(\mathrm{ml})$ & 32 & 22 \\
\hline
\end{tabular}

Table 3. List of Short and long term complications following surgery.

\begin{tabular}{|l|l|l|}
\hline Complication parameter & Short term complications & Long term complications \\
\hline Number of morbid patients (n, \%) & $7(33.3)$ & $4(19)$ \\
\hline Clavien-DindoClassificaiton (n) & & \\
\hline Grade I & 2 & 0 \\
\hline Grade II & 3 & 1 \\
\hline Grade IIIa & 0 & 2 \\
\hline Grade IIIb & 1 & 0 \\
\hline Grade IV & 1 & 1 \\
\hline Grade V (mortality) & 1 & 1 \\
\hline Complications (n) & & \\
\hline Metabolic acidosis & 1 & \\
\hline Prolonged Ileus & 3 & \\
\hline Wound dehiscence/ Burst abdomen & 1 & \\
\hline Respiratory complications & 1 & \\
\hline Urinary tract infection ( pyelonephritis) & 2 & 2 \\
\hline Acute/chronic Renal insufficiency & 1 & \\
\hline Sepsis & 1 & 1 \\
\hline Ureteroenteric stricture/obstruction & 0 & \\
\hline Ureteroenteric leakage/disruption & 1 & \\
\hline Enteric anastomotic leakage/ disruption & 1 & \\
\hline Intestinal obstruction & 0 & \\
\hline Urethral stricture & 0 & \\
\hline
\end{tabular}




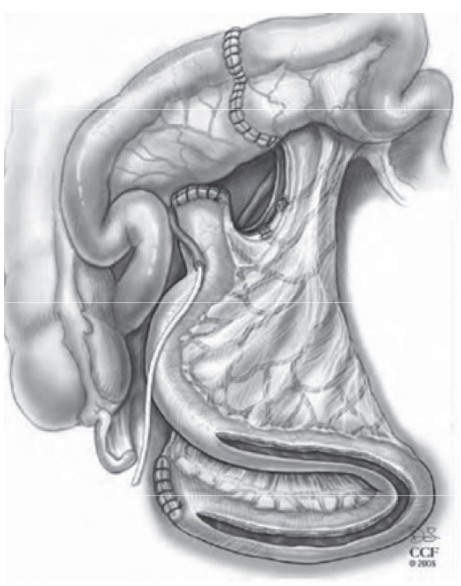

(A)

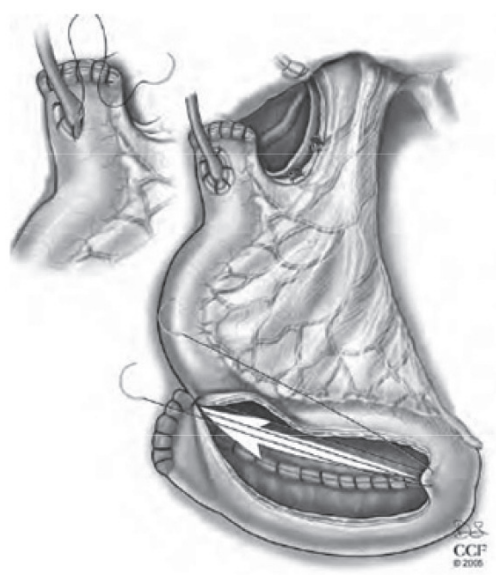

(B)

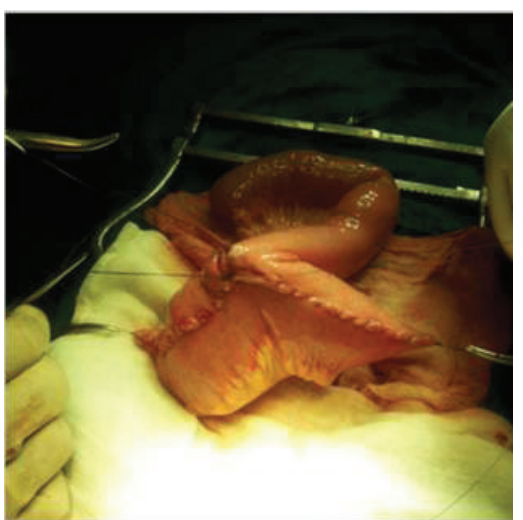

(C)

Fig 1.(A) $45-55 \mathrm{~cm}$ of distal ileum is isolated, beginning $15-20 \mathrm{~cm}$ proximal to the ileocecal valve. $10-15 \mathrm{~cm}$ of the proximal segment (afferent limb) is left intact for attachment to the ureters. The small bowel anastomosis is completed and 30-45 cm of the ileal segement is detubularised along the antimesenteric border. (B) The back wall of the neobladder is closed with running absorbable suture. The neobladder is then folded end-to-end and closed with additional running suture. The end to side ureteral-intestinal anastomosis is done overstent (C) Intraoperative appearance of the completed neobladder ready for the neobladder-urethral anastomsis.

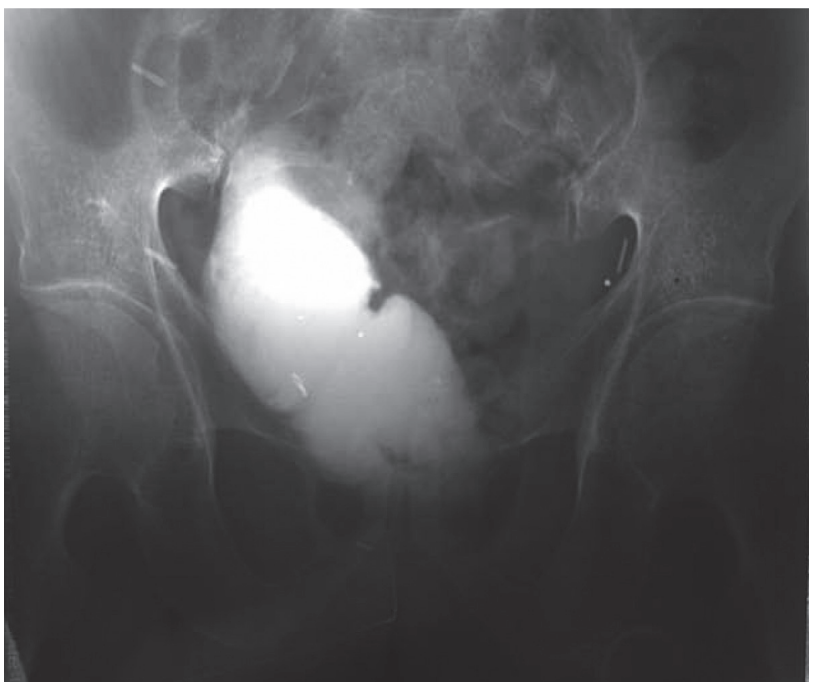

Fig 2. Pouchogram of ileal studer orthotopic neobladder at 3 weeks.

\section{DISCUSSION}

Radical cystectomy (RC) with pelvic lymphadenectomy has been established as the standard for the treatment of muscle invasive and high risk bladder cancer. It effectively removes the primary tumor and the regional lymph nodes that may contain metastasis in about 25 $\%$ of patients undergoing this procedure ${ }^{11,12}$. According to the treatment EUA Guidelines, patients with non metastatic, operable invasive bladder cancer are treated with radical cystectomy, pelvic lymphadenectomy and urinary diversion ${ }^{13}$. Contemporary objectives of the urinary diversion should consider quality of life issues, eliminating the need for cutaneous urostomy, the need for a urostomy appliance and the need for intermittent catheterization while maintaining a more natural voiding pattern that allows micturation through the intact native urethra ${ }^{14}$.

The characteristics of an ideal intestinal bladder substitution are low pressure, adequate capacity and high compliance, which provide continence and voluntary control of voiding without residual urine in order to provide improved quality of life and self image. The Studer orthotopic ileal neobladder has the advantages of satisfactory continence rate, absence of urinary leakage and freedom from intermittent catheterization $^{15}$. In addition, renal function is preserved, and intestinal malabsorption and fluid and electrolyte imbalances are avoided ${ }^{8,16}$. These features have rendered the Studer bladder substitution one of the most ideal orthotopic urinary diversions. 
The early and late complications rates in our series were $33.3 \%$ and $19 \%$ respectively. Also the complications related mortality is $1(4 \%)$ in both early and late period. Reported rates and types of complications vary widely. Studer et al. over twenty years experienced overall perioperative complications of $12.6 \%$ (61 out of 482) that required prolonged hospital stay and late complications rate of $23.8 \%$ (115 out of 482 ). ${ }^{17}$ The result of the previously reported large numbered studies involving orthotopic neobladder subsitution showed early and late modbidity and mortality rate of (11.0-57.2\%/2.0-3.1\% and 19.0-40.8\%/ 5.7$8.3 \%$, respectively $)^{16,18-21}$. Morbidity of RC has been significantly influenced by many factors, including age, baseline underlying diseases, operative skills and methods and disease status. Most early complications are bleeding, neurologic, thromboembolic, cardiac and pulmonary complications. The early diversion related complications are wound related, gastrointestinal related, genitourinary and infection. Similarly late complications that may be related to the diversion itself include loss of kidney funciton, pyelonephritis, anastomotic related, urinary tract stones, and incontinence ${ }^{6,22}$.

A wide range in prevalence of acidosis has been reported among patients with neobladder, as has the need for early or long-term sodium bicarbonate therapy. All of our patients received 3-6 gm of Sodium Bicarbonate orally for 3 to 4 weeks. The rate of metabolic acidosis ranges from $5.5 \%$ to $13.3 \%$ and largely depend upon the bowel segment used for neobladder reconstruction ${ }^{23}$. Bacterial colonization of the neobladder diversion occurs in $40-80 \%$ of patients. Colonization is usually secondary to residual urine, and nearly $6 \%$ patient progress to overt pyelonephritis at some point following urinary diversion ${ }^{24-26}$. In the absence of obstruction, upper urinary tract infections can be managed with an administration of culturespecific antibiotics. In our cases, two $(9.5 \%)$ patients had recurrent pyelonephritis. Ureterointestinal and urethral stricture are the most difficult complications. The reported incidence of this complication is approximately $2.4-9 \%{ }^{22,27}$.

The functional capacity of neobladder increases gradually with time ${ }^{28}$. The mean functional capacity of neobladder was $280 \mathrm{ml}$ and $345 \mathrm{ml}$ in 6 months and one year follow up. An intact urethral sphincter mechanism and pelvic floor are responsible for the continence mechanism ${ }^{22,29,30}$. Additional factors that may influence continence include urethral length and sensitivity, patient age and mental status, intact pelvic nerve supply to the rhabdosphincter, completeness of voiding, and presence or absence of bacteriuria.

In our study complete day and night time continence was observed in $82 \%$ and $33.3 \%$ of the patients respectively at the end of one year. $66 \%$ of the patients have some degree of night time incontinence. Most series reported complete day and night time continence of range $89 \%-94 \%$ and $29 \%-36 \%{ }^{22,28}$. Nocturnal incontinence following orthotopic bladder substitution results from the absence of a neuro-feedback to the brain, of sphincter-detrusor reflex, as well as decreased sphincter tone at night ${ }^{30}$. The functional voiding outcome with an orthotopic neobladder is excellent with high continence rates and generally good bladder emptying that offers higher quality of life in comparison to incontinent diversion ${ }^{15}$.

Small sample size and short follow up with subjective assessment of urine flow were some of the limitations.

\section{CONCLUSIONS}

Our results with the Studer orthotopic ileal neobladder have an acceptable complication rate and technically feasible, with good functional outcome. However the impact of urinary diversion on the quality of life still remains controversial, although long-term data argue in favor of orthotopic bladder substitution

\section{REFERENCES}

1. Jemal A, Bray F, Center MM, Ferlay J, Ward E, Forman D. Global cancer statistics. CA Cancer J Clin. 2011.Mar-Apr;61(2):69-90. doi. org/10.3322/caac.20107. PMid:21296855.

2. Lopez-Beltran A. Bladder cancer: clinical and pathological profile. Scand $J$ Urol Nephrol Suppl. 2008 Sep(218):95-109. doi.org/10.1080/03008880802325226. PMid:18815924

3. Lamichhane N, Nepal U, Neupane BR, Thakur $B K$, Shrestha BM. Orthotopicneobladder urinary diversion for carcinoma of urinary bladder. $J$ Nepal Health Res Counc. 2012 Sep;10(22):201- 
3. PMid:23281451.

4. ParkJ, Ahn H. Radical cystectomy and orthotopic bladder substitution using ileum. Korean J Urol. 2011.Apr;52(4):233-40. doi.org/10.4111/ kju.2011.52.4.233. PMid:21556208

5. Hautmann RE, Abol-Enein $H$, Hafez $K$, Haro I, Mansson W, Mills RD, et al. Urinary diversion. Urology. 2007,Jan;69(1 Suppl):17-49. doi.org/10.1016/j.urology.2006.05.058 PMid:17280907

6. Hautmann RE. Urinary diversion: ileal conduit to neobladder. J Urol. 2003;169(3):834-42. doi.org/10.1097/01.ju.0000029010.97686.eb PMid:12576795

7. Studer UE, Ackermann D, Casanova GA, Zingg EJ. Three years' experience with an ileal low pressure bladder substitute. $\mathrm{Br} J$ Urol. 1989 ;63(1):43-52. doi.org/10.1111/j.1464-410X.1989. tb05122.x PMid:2920259

8. Studer UE, Danuser H, Merz VW, Springer $J P$, Zingg EJ. Experience in 100 patients with an ileal low pressure bladder substitute combined with an afferent tubular isoperistaltic segment. J Urol. 1995 Jul;154(1):49-56.doi. org/10.1097/00005392-199507000-00019, doi. org/10.1016/S0022-5347(01)67223-9

9. Studer UE, Zingg EJ. Ilealorthotopic bladder substitutes. What we have learned from 12 years' experience with 200 patients. Urol Clin North Am. 1997 Nov;24(4):781-93. doi.org/10.1016/ S0094-0143(05)70420-1

10. Kim SH, Yu A, Jung JH, Lee YJ, Lee ES. Incidence and risk factors of 30-day early and 90-day late morbidity and mortality of radical cystectomy during a 13-year follow-up: a comparative propensity-score matched analysis of complications between neobladder and ileal conduit. Jpn J Clin Oncol. 2014 Jul;44(7):67785. doi.org/10.1093/jjco/hyu051 PMid:24791782

11. Dindo D, Demartines $N$, Clavien PA. Classification of surgical complications: a new proposal with evaluation in a cohort of 6336 patients and results of a survey. Ann Surg. 2004 Aug;240(2):205-13. doi.org/10.1097/01. sla.0000133083.54934.aePMid:15273542
12. Lerner SP, Skinner E, Skinner DG. Radical cystectomy in regionally advanced bladder cancer. Urol Clin North Am. 1992 Nov; 19(4): 71323. PMid: 1279876

13. Stein JP, Lieskovsky G, Cote R, Groshen S, Feng $A C$, Boyd $S$, et al. Radical cystectomy in the treatment of invasive bladder cancer: long-term results in 1,054 patients. J Clin Oncol. $2001 \mathrm{Feb}$ 1;19(3):666-75. PMid:11157016

14. Oosterlinck W, Lobel B, Jakse G, Malmstrom PU, Stockle M, Sternberg C. Guidelines on bladder cancer. Eur Urol. 2002 Feb;41(2):105-12. doi. org/10.1016/S0302-2838(01)00026-4

15. Lilien OM, Camey M. 25-year experience with replacement of the human bladder (Camey procedure). J Urol. 1984 Nov;132(5):886-91. PMid:6387181

16. Weijerman PC, Schurmans JR, Hop WC, Schroder FH, Bosch JL. Morbidity and quality of life in patients with orthotopic and heterotopic continent urinary diversion. Urology. 1998 Jan;51(1):516. doi.org/10.1016/S0090-4295(97)00461-5

17. Studer UE, Burkhard FC, Schumacher M, Kessler TM, Thoeny H, Fleischmann A, et al. Twenty years experience with an ilealorthotopic low pressure bladder substitute--lessons to be learned. J Urol. 2006 Jul;176(1):161-6. doi. org/10.1016/S0022-5347(06)00573-8

18. Gore JL, Yu HY, Setodji C, Hanley JM, Litwin MS, Saigal CS. Urinary diversion and morbidity after radical cystectomy for bladder cancer. Cancer. 2010 Jan 15;116(2):331-9. doi.org/10.1002/ cncr.24763PMid:19924831

19. Novotny $V$, Hakenberg OW, Wiessner D, Heberling $U$, Litz RJ, Oehlschlaeger $S$, et al. Perioperative complications of radical cystectomy in a contemporary series. Eur Urol. 2007 Feb;51(2):397-401; discussion -2.

20. Yokoo A, Hirose T, Mikuma N, Tsukamoto T. Ilealneobladder for bladder substitution after radicalcystectomy. IntJUrol.1998May;5(3):21924. doi.org/10.1111/j.1442-2042.1998.tb00593. xPMid:9624551

21. Ramani VA, Bromage SJ, Clarke NW. A contemporary standard for morbidity and 
outcome after radical cystectomy. BJU Int. 2009 Sep;104(5):628-32.doi.org/10.1111/j.1464410X.2009.08506.xPMid:19388998

22. Hautmann RE, Volkmer BG, Schumacher $M C$, Gschwend JE, Studer UE. Longterm results of standard procedures in urology: the ilealneobladder. World $J \quad$ Urol. $2006 \quad$ Aug;24(3):305-14. doi.org/10.1007/s00345-006-0105zPMid:16830152

23. Racioppi M, D'Addessi A, Fanasca A, Mingrone $G$, Capristo E, Benedetti $G$, et al. Acid-base and electrolyte balance in urinary intestinal orthotopic reservoir: ileocecalneobladder compared with ilealneobladder. Urology. 1999 Oct;54(4):629-35.doi.org/10.1016/S00904295(99)00317-9

24. Wullt B, Holst E, Steven $K$, Carstensen J, Pedersen J, Gustafsson E, et al. Microbial flora in ileal and colonic neobladders. Eur Urol. 2004 Feb;45(2):233-9. doi.org/10.1016/j. eururo.2003.09.002PMid:14734012

25. Akerlund S, Campanello M, Kaijser B, Jonsson $O$. Bacteriuria in patients with a continent ileal reservoir for urinary diversion does not regularly require antibiotic treatment. Br J Urol. 1994 Aug;74(2):177-81. doi.org/10.1111/j.1464-
410X.1994.tb16582.xPMid:7921934

26. Wood DP, Jr., Bianco FJ, Jr., Pontes JE, Heath $M A$, DaJusta D. Incidence and significance of positive urine cultures in patients with an orthotopicneobladder. $J$ Urol. 2003 Jun;169(6):2196-9. doi.org/10.1097/01.ju.00000 67909.98836.91PMid:12771748

27. Jensen JB, Lundbeck $F$, Jensen KM. Complications and neobladder function of the Hautmannorthotopicilealneobladder. BJU Int. 2006 Dec;98(6):1289-94. doi.org/10.1111/ j.1464-410X.2006.06449.xPMid:17034505

28. Nam JK, Kim TN, Park SW, Lee SD, Chung MK. The Studerorthotopicneobladder: longterm (more than 10 years) functional outcomes, urodynamic features, and complications. Yonsei MedJ. 2013 May 1;54(3):690-5. doi.org/10.3349/ ymj.2013.54.3.690PMid:23549816

29. Light JK. Continence mechanisms following orthotopic bladder substitution. Scand J UrolNephrol Suppl. 1992;142:95-7. PMid:1496325

30. Steers WD. Voiding dysfunction in the orthotopicneobladder. World J Urol. 2000 Oct;18(5):330-7. doi.org/10.1007/ s003450000146PMid:11131310 